\title{
Sledgehammer to Scalpel: Broad Challenges to the Heart and Other Tissues Yield Specific Cellular Responses via Transcriptional Regulation of the ER-Stress Master Regulator ATF6 $\alpha$
}

\author{
Winston T. Stauffer, Adrian Arrieta, Erik A. Blackwood and Christopher C. Glembotski * \\ Department of Biology, San Diego State University Heart Institute, San Diego State University, San Diego, \\ CA 92182, USA; wstauffe@gmail.com (W.T.S.); aarrieta1335@gmail.com (A.A.); \\ eblackwo@alumni.nd.edu (E.A.B.) \\ * Correspondence: cglembotski@sdsu.edu; Tel.: +1-619-594-2958
}

Received: 24 December 2019; Accepted: 6 February 2020; Published: 8 February 2020

\begin{abstract}
There are more than 2000 transcription factors in eukaryotes, many of which are subject to complex mechanisms fine-tuning their activity and their transcriptional programs to meet the vast array of conditions under which cells must adapt to thrive and survive. For example, conditions that impair protein folding in the endoplasmic reticulum (ER), sometimes called ER stress, elicit the relocation of the ER-transmembrane protein, activating transcription factor $6 \alpha$ (ATF6 $\alpha$ ), to the Golgi, where it is proteolytically cleaved. This generates a fragment of ATF6 $\alpha$ that translocates to the nucleus, where it regulates numerous genes that restore ER protein-folding capacity but is degraded soon after. Thus, upon ER stress, ATF6 $\alpha$ is converted from a stable, transmembrane protein, to a rapidly degraded, nuclear protein that is a potent transcription factor. This review focuses on the molecular mechanisms governing ATF6 $\alpha$ location, activity, and stability, as well as the transcriptional programs ATF6 $\alpha$ regulates, whether canonical genes that restore ER protein-folding or unexpected, non-canonical genes affecting cellular functions beyond the ER. Moreover, we will review fascinating roles for an ATF6 $\alpha$ isoform, ATF6 $\beta$, which has a similar mode of activation but, unlike ATF6 $\alpha$, is a long-lived, weak transcription factor that may moderate the genetic effects of ATF6 $\alpha$.
\end{abstract}

Keywords: ATF6 $\alpha$; ATF6 $\beta$; ER stress; transcriptional regulation; proteostasis; endoplasmic reticulum; UPR; OASIS; basic leucine-zipper; cardiac

\section{Introduction}

In eukaryotes, transcription is a highly complex and regulated process involving multiple levels of control. For example, epigenetic regulation of transcription through histone modifications can alter chromatin structure in ways that determine transcriptional magnitude [1]. The positioning of promoter and enhancer sequences in genes governs the recruitment of the polymerases, transcription factors, and other transcriptional machinery [2]. Moreover, transcription initiation, transcript elongation, splicing, and termination are all subject to regulatory checkpoints that serve as determinants of transcriptional programs [3]. The processes that determine what genes are regulated by a given transcription factor are both intricate and varied. At the least, these complex regulatory processes provide a mechanism for the fine-tuning of transcriptional programs involved in numerous responses including development, differentiation, immune responses and responses to stress. Moreover, transcription factors that are broadly expressed can be activated by cell-specific stimuli and they can regulate cell-specific transcriptional programs. Thus, there is a vast and, for the most part, uncharacterized array of genetic responses for even well studied transcription factors with known, or canonical roles. It has been 
estimated that approximately $8 \%$ of the human genome encodes approximately 2600 transcription factors [4], many of which fall into families that are sometimes based on location or structure, such as zinc finger, homeodomain, nuclear hormone receptors, basic helix-loop-helix and basic leucine zipper (bZIP) [5]. One of the most intriguing features of many regulated transcription factors is their mechanism of activation [6]. For example, certain stress-regulated transcription factors are responsive to oxygen depletion (e.g., hypoxia-inducible factor $1 \alpha$ (HIF1 $\alpha)$ [7], oxidative stress (e.g., nuclear factor erythroid 2-like factor 2 (NRF2)) [8] and growth factors (e.g., serum response factor (SRF)) [9]. This review focuses on activating transcription factor $6 \alpha$ (ATF6 $\alpha$ ), a transcription factor that was originally found to be activated by ER proteotoxic stress [10], i.e., protein-misfolding in the ER, but more recently has been found to be activated by a wider array of stresses [11].

\section{ATF6 $\alpha$ Overview}

The ER unfolded protein response (UPR) responds to stresses that perturb ER protein folding capacity, i.e., ER stresses that result in the accumulation of misfolded proteins in the ER lumen. ATF6 $\alpha$ is a master regulator of one of the three main branches of the ER UPR, each of which is initiated by the ER-transmembrane proteins, protein kinase R-like ER kinase (PERK), inositol-requiring protein-1 (IRE1), and ATF6 $\alpha$ (Figure 1A) [12]. In response to misfolded proteins, PERK dimerization results in the activation of its cytosolic kinase function, leading to autophosphorylation and the phosphorylation of numerous proteins outside the ER, including eukaryotic initiation factor $2 \alpha$ (eIF2 $\alpha$ ) (Figure 1B). eIF2 $\alpha$ phosphorylation by PERK confers a global arrest of translation, thus decreasing the protein-folding load on the ER machinery [13]. Upon ER stress, IRE1 also dimerizes and becomes autophosphorylated on its cytosolic domain, which activates it as an RNA splicing enzyme that converts $x$-box-binding protein 1 (XBP-1) mRNA to a so-called spliced form that encodes an active transcription factor, XBP-1s [14] (Figure 1C). In contrast to PERK and IRE1, when ATF6 $\alpha$ senses misfolded proteins in the ER, it translocates to the Golgi (Figure 1D), where it is proteolytically clipped. The N-terminal fragment liberated as a result of this proteolysis [15] is a basic leucine zipper (bZIP) transcription factor related to others in the activating transcription factor/cAMP response element binding (ATF/CREB) family [16,17]. ATF $6 \alpha$ was the first of its subgroup of the ATF/CREB family to be identified, and since then a related isoform, ATF6 $\beta$, which has significant homology to ATF $6 \alpha$, has been assigned to the ATF/CREB family. ATF $6 \beta$ can bind to and transcriptionally induce many of the same genes as ATF6 $\alpha$, but ATF6 $\beta$ is a much weaker transcriptional activator, perhaps serving as an endogenous modulator of ATF $6 \alpha$, as described below $[18,19]$.

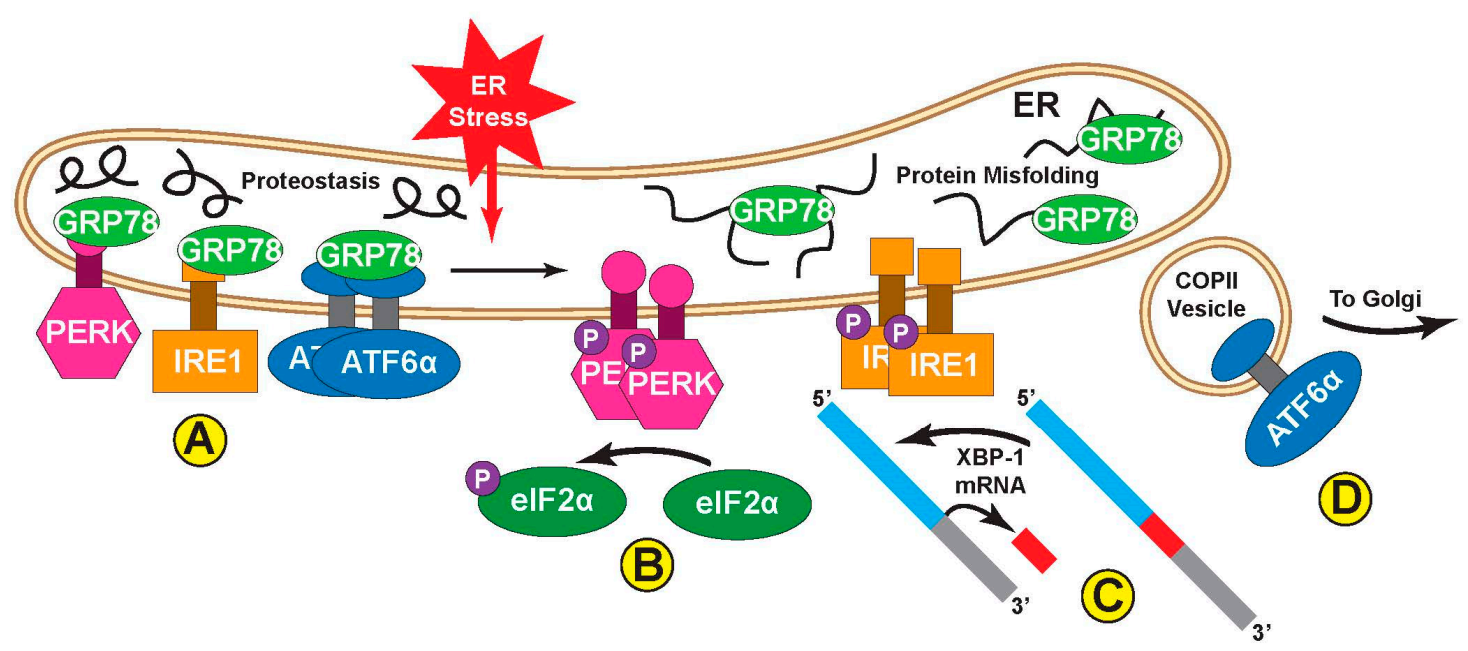

Figure 1. Overview of the activation of the three branches of the ER UPR. (A) PERK, IRE1, and ATF6 $\alpha$ are all ER transmembrane proteins with cytosolic and luminal domains that act as sensors to detect the build-up of misfolded proteins characteristic of ER stress. When the capacity of the ER to translate 
and fold nascent proteins is sufficient to meet demand, protein misfolding is minimal and the ER is in proteostasis. During such periods, canonical ER chaperone GRP78 (also known as BiP) binds the luminal domains of all three UPR sensors and helps hold them in an inactive state. PERK and IRE1 are held in monomeric form, while inactive ATF6 $\alpha$ is an oligomer. Upon induction of ER stress, by challenges such as ischemia, oxidative stress, or increases in ER protein flux, nascent ER proteins begin to misfold and can build up in the ER lumen. GRP78 then actively unbinds the ER sensors to bind the misfolded proteins and promote their proper folding. Simultaneously, the three sensor branches become active; (B) PERK, which has cytoplasmic kinase domains, dimerizes with itself and becomes autophosphorylated. It then phosphorylates its substrate, eIF2 $\alpha$, in the cytoplasm which acts to slow translation of all non-UPR-related proteins; (C) IRE1, which has cytoplasmic kinase and endonuclease domains, also dimerizes and is autophosphorylated. This activates its endonuclease function to splice out a section of XBP-1 mRNA to create a new, spliced transcript, XBP-1s, which codes for a transcription factor that upregulates some UPR-related transcripts; (D) ATF6 $\alpha$, which is both a sensor of ER stress and a UPR-effector transcription factor, becomes monomeric upon induction of ER stress, whereupon it exits the ER via COPII vesicles and transits to the Golgi, where the active transcription factor is liberated from the transmembrane domain by Golgi proteases.

\section{ATF6 $\alpha$ Activation}

In its transcriptionally inactive state, ATF6 $\alpha$ is anchored in the ER partly by binding to the well-characterized ER chaperone, glucose-regulated protein $78 \mathrm{kD}$ (also known as BiP but referred to here as GRP78) [20]. Under these conditions ATF6 $\alpha$ forms oligomers via intermolecular disulfide bonds between conserved cysteine residues in its luminal domain [21,22] (Figure 2A). During periods of ER stress, brought on by pathophysiological conditions including ischemia [23], GRP78 is actively diverted to bind to the misfolded proteins that accumulate in the ER lumen, thus releasing its hold on ATF6 $\alpha$ [24] (Figure 2B). Subsequently, the disulfide bonds in ATF6 $\alpha$ become reduced, which decreases ATF $6 \alpha$ oligomerization, leading to the translocation of ATF6 $\alpha$ to the Golgi (Figure 2C), where it can then be proteolytically cleaved by regulated intramembrane proteolysis (RIP) by the Golgi resident proteases, site 1 protease (S1P) and site 2 protease (S2P) [25] (Figure 2D). This mechanism of activation involving the release of ATF6 $\alpha$ by GRP78 may be shared with PERK and IRE-1, thus fostering the activation of all three branches of the ER stress response [26,27]. However, more recently, other paradigms of ATF6 $\alpha$ activation have emerged. For example, thrombospondin 4 (Thbs4), a secreted calcium-binding protein, was shown to interact with ATF6 $\alpha$ during stress and to promote its shuttling to the Golgi (Figure 2C,D). In this study, it was shown that without Thbs4, ATF6 $\alpha$ activation was blunted, as were the other ER stress branches, suggesting a broader role for Thbs4 in the ER UPR [28]. Recently, multiple protein oxidoreductases have been shown to associate with, and reduce ATF6 $\alpha$ during ER stress; this reduction, which also causes the dissociation of ATF6 $\alpha$ oligomers, is thought to facilitate the movement of ATF6 $\alpha$ out of the ER to the Golgi [21,22]. In particular, the ER-resident protein disulfide isomerase (PDI), PDIA5, was shown to be necessary for the proper reduction of ATF6 $\alpha$ before packaging into Golgi-bound vesicles in cancer cells [29]. Also, the PDI, ER protein 18 (ERp18), was found to associate with, and reduce ATF6 $\alpha$ during ER stress and, in its absence, ATF6 $\alpha$ was improperly processed by the S1P/S2P proteases, which were unable to release its soluble nuclear form [30]. Small molecule compounds have been discovered which take advantage of this reduction/activation dynamic for targeted, specific inhibition or activation of ATF6 $\alpha$. A class of pyrazole amides, dubbed Ceapins, have been discovered [31], which inactivate ATF6 $\alpha$ by inhibiting its transport from the ER to the Golgi (Figure 2B). Furthermore, ATF6 $\alpha$ that has been retained in the ER by Ceapins is still able to be processed by the Golgi proteases, if those proteases are experimentally relocated from the Golgi to the ER. Indeed, the fact that Ceapins have no effect on S1P/S2P forms the likely basis for why Ceapins are so specific for ATF6 $\alpha$ [32]. Other compounds, such as AEBSF [33] or PF429242 [34], also inhibit ATF6 $\alpha$, but do so by inactivating serine proteases, including S1P; thus, a caveat to these compounds is that they impact other proteins that are activated by RIP, such as the 
transcription factor, sterol regulatory element binding protein (SREBP), as well as some other members of the ATF6 subgroup, including ATF6 $\beta$ (see below) [31,32]. Another chemical recently discovered in a high-throughput screen, is a selective ATF6 $\alpha$ activator [35]. This chemical, called compound 147, promotes the formation of ATF $6 \alpha$ monomers and thus enhances the transit of ATF $6 \alpha$ from the ER to the Golgi and subsequent proteolytic cleavage of ATF6 $\alpha$ to its active form [36] (Figure 2B). Compound 147 is specific for ATF6 $\alpha$ and does not activate other members of the ATF6 family [35]. Likewise, the naturally occurring sphingolipids dihydrosphingosine (DHS) and dihydroceramide (DHC) have also been shown to specifically activate ATF6 $\alpha$ [37] (Figure 2B), though the resulting upregulation of ATF6 target transcripts can vary significantly depending on the activation stimulus (see below). These reagents are very useful for studies requiring selective pharmacologic manipulation of ATF6 $\alpha$ activity and, as will be discussed below, may also be of future utility in disease treatment, where ATF6 $\alpha$ is a therapeutic target.

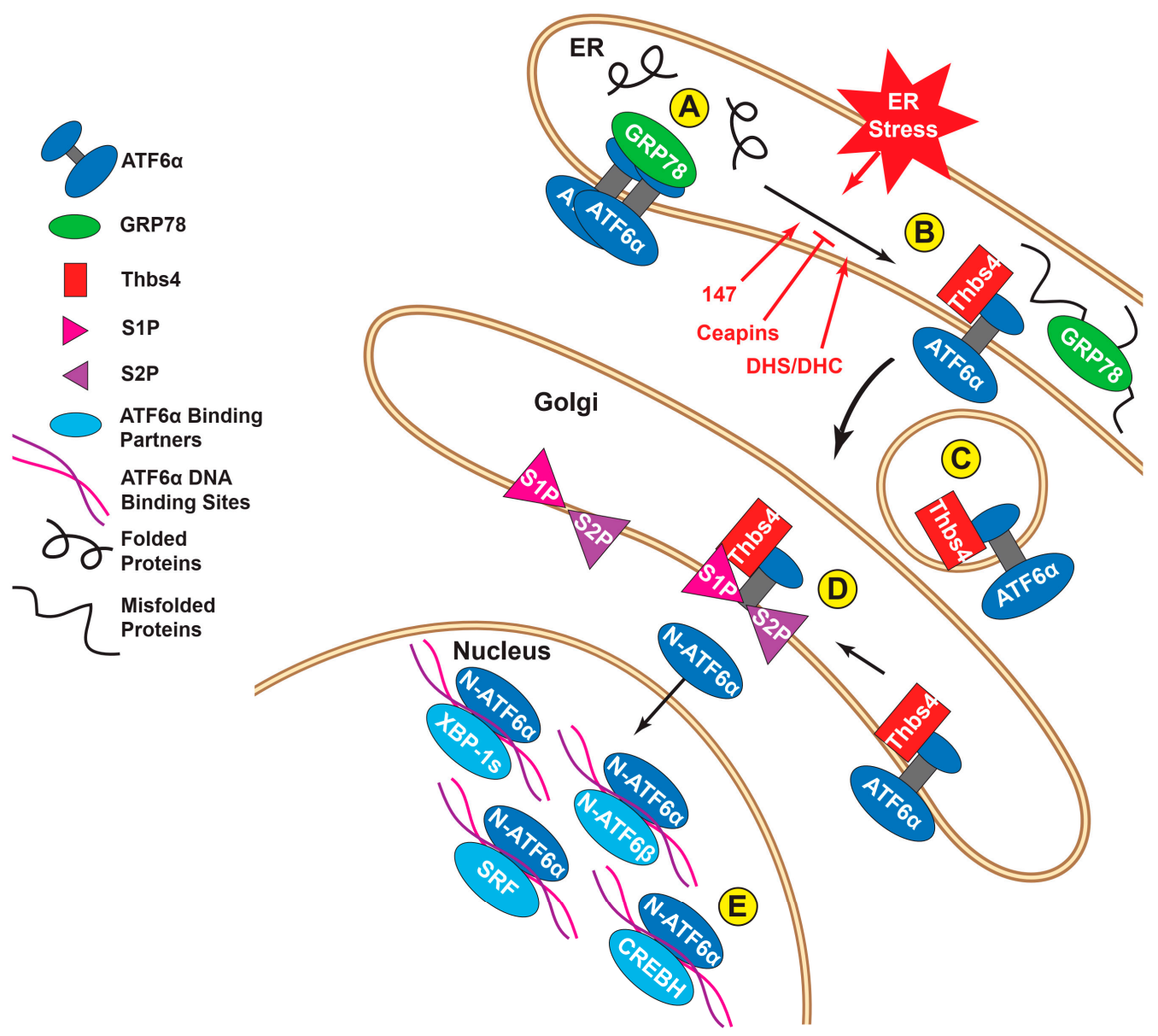

Figure 2. Focus on ATF6 $\alpha$ activation. (A) In the absence of ER stress, ATF6 $\alpha$ exists in an oligomeric state and its luminal domain associates with GRP78; (B) During ER stress, GRP78 relocates from ATF6 $\alpha$ to misfolded proteins; ATF6 $\alpha$ is then reduced to a monomeric state. Chemicals, such as compound 147, or certain sphingolipids, can promote ATF6 $\alpha$ relocation out of the ER in the absence of overt ER stress. Other chemicals, called Ceapins, inhibit this process, even during ER stress; (C) ATF6 $\alpha$ and binding partners, such as Thbs4, are packaged into COPII vesicles and transit to the Golgi; (D) Golgi resident proteases, S1P and S2P, cleave the N-terminal cytosolic region of ATF6 $\alpha$ from the transmembrane domain. The soluble N-terminal fragment (N-ATF6 $\alpha$ ) is then free to enter the nucleus where it binds to target genes and influences transcription; (E) N-ATF6 $\alpha$ binds DNA as a homodimer but is also known to form heterodimers with a number of other nuclear proteins, including N-ATF6 $\beta, X B P-1 \mathrm{~s}$, SRF, and CREBH. Binding different partners can alter which transcripts N-ATF6 $\alpha$ induces. 


\section{ATF6 $\alpha$ Transcriptional Activity and Degradation}

Once cleaved, the N-terminal fragment of ATF6 $\alpha$ is liberated from the ER and, via a nuclear localization sequence, it translocates to the nucleus where, along with a variety of potential binding partners including itself [38], it can selectively activate transcription (Figure 2E). The transactivation domain (TAD) of ATF6 $\alpha$ was found to contain an eight amino acid sequence with homology to the Herpes simplex viral transcription factor, VP16 [39] (Figure 3A,B). This sequence, referred to as VN8 in that same study, has been shown to confer both high transcriptional potency and a high rate of degradation to ATF6 $\alpha$. Amongst the ATF6 $\alpha$ subfamily, only ATF6 $\alpha$ possesses a VN8 sequence in its transactivation domain. Indeed, while other unrelated transcription factors are also known to be quickly degraded when active [40], ATF6 $\alpha$ is the only such mammalian transcription factor known to have a VN8 sequence [39]. Mutating specific residues in the VN8 region of ATF6 $\alpha$ is sufficient to significantly reduce its transcriptional potency and significantly increase its stability [18]. It is interesting to note that while ATF6 $\beta$ is relatively similar to ATF6 $\alpha$ in most areas it does not have a VN8 domain; consistent with this, ATF6 $\beta$ is a comparatively poor transcription factor and it is degraded very slowly [41] (Figure 3C,D). Moreover, mutation studies demonstrated that transferring the VN8 domain of ATF6 $\alpha$ onto ATF6 $\beta$ transformed ATF6 $\beta$ from a long-lived, weak transcription factor into a short-lived, strong transcription factor, resembling the characteristics of ATF6 $\alpha$ [18]. The exact mechanism by which activated ATF6 $\alpha$ is rapidly degraded remains unknown. While ATF6 $\alpha$ has been reported to be ubiquitylated [42,43] and while it is known to be degraded by proteasomes [39,44], less is known about the timing, location, and importance of these events. In so far as the VN8 sequence of VP16 is shared with ATF6 $\alpha$, it is interesting to note that the ubiquitin-proteasome system has been shown to be required for the activity of VP16 [45]. In that study, a specific subunit of the 19S proteasome, $26 \mathrm{~S}$ proteasome regulatory subunit 8 (SUG-1), was required to ubiquitylate and degrade VP16. Interestingly, this subunit was also required for the transcriptional activity of VP16, suggesting that, at least for VP16, ubiquitylation is a requirement for its transcriptional activity, and is not a consequence of its transcriptional activation [45]. ATF6 $\alpha$ has also been shown to be post-translationally modified in other ways, such as glycosylation [46] and SUMOylation [47], and it is certainly true that many post-translational modifications, including ubiquitylation, have been reported to be essential regulators of other transcription factors [48]. Meanwhile, there are varying reports concerning whether nuclear proteasomes are functional and whether ubiquitylated nuclear proteins, potentially including ATF6 $\alpha$, are degraded in the nucleus, or whether they are first transported back to the cytosol [49-51].

\section{ATF6 $\alpha$ Dimerization and Nuclear Binding Partners}

ATF6 $\alpha$, like other bZIP transcription factors, forms homodimers, as well as heterodimers with other transcription factors, not all of which are members of the ATF/CREB family; presumably, it is through selective dimerization that the transcriptional programs regulated by ATF6 can be fine-tuned [52] (Figure 2E). ATF6 $\alpha$ was first discovered as a dimerization partner of serum response factor (SRF), a MADS-box transcription factor that upregulates a variety of genes through serum response elements (SRE) [53]. SRF binding to ATF6 $\alpha$ was shown to enhance the activation of SRF-responsive transcript expression [54]. ATF6 $\alpha$ binding to its target DNA sequences is also dependent on interactions with other proteins, such as NF-Y, which also binds these gene targets [55]. Other binding partners that synergistically enhance the activity of ATF6 $\alpha$ include YY-1 [56], fellow ER stress response effector XBP-1s [57], PGC-1 $\alpha$ [58], ERR $\gamma$ [59], and CREBH [60] (see below). Additionally, binding partners have the potential to negatively regulate the transcriptional activity of ATF $6 \alpha$, as is the case with ATF6 $\beta$ [41] (see below). The mechanisms that determine ATF6 $\alpha$ binding partners remain unknown. It seems unlikely that ATF6 $\alpha$ homo- or heterodimerization could begin in the ER because, as before, only monomeric ATF6 $\alpha$ is packaged into COPII vesicles for exit from the ER [22]. Dimerization could take place in the Golgi, though when cleavage of ATF6 $\alpha$ is experimentally forced to take place in the ER, using mutant forms of S1P/S2P proteases engineered with C-terminal KDEL ER retention sequences, ATF6 $\alpha$ is processed normally and is functional [61]. Lastly ATF6 $\alpha$ may find its binding partners after 
translocation to the nucleus, perhaps in the process of binding DNA sequences. Indeed, in the case of bZIP-bZIP dimers, the dimer structure of the combined transcription factors is required for proper binding to the major groove of the DNA [62].

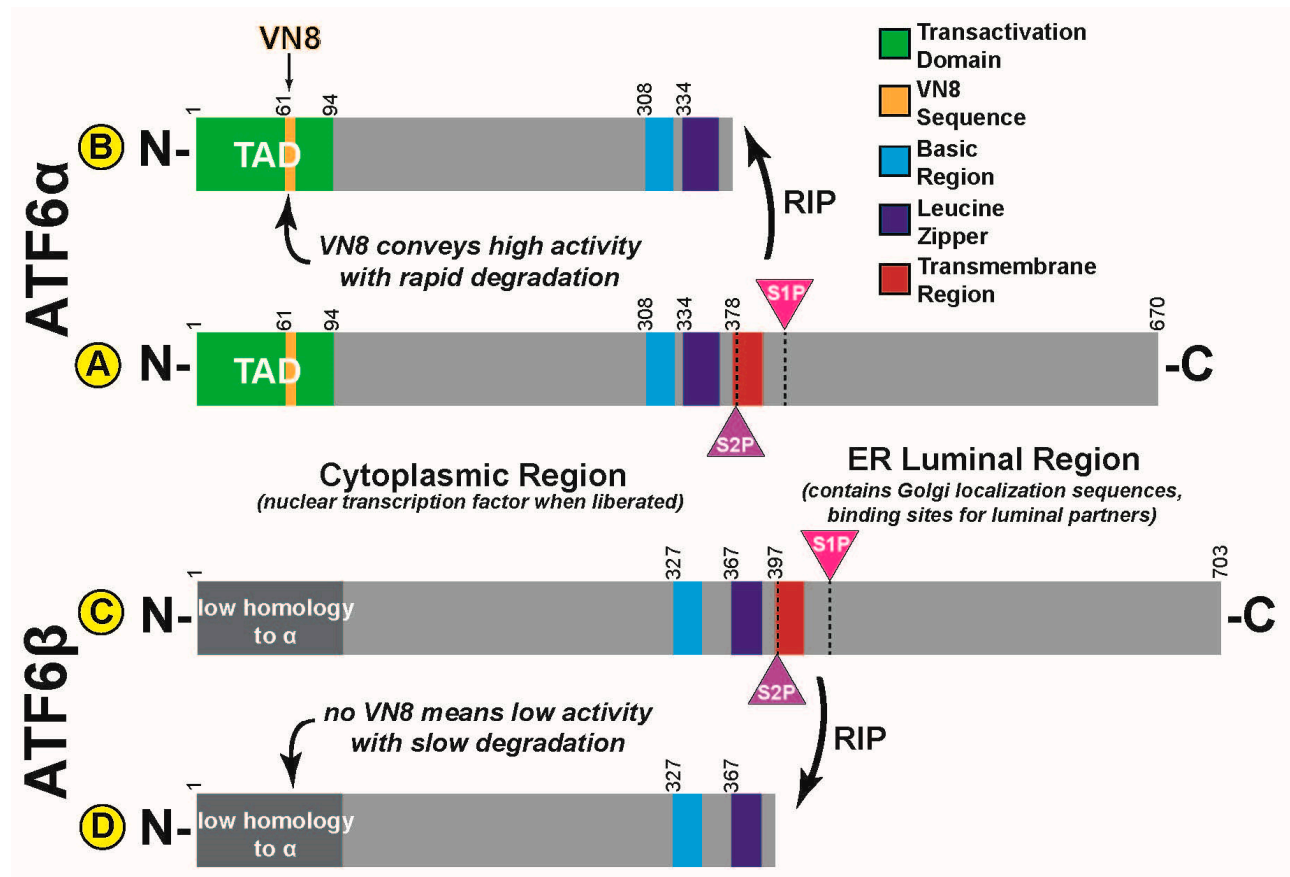

Figure 3. Structural comparison between ATF6 $\alpha$ and $\beta$. (A) Full length ATF6 $\alpha$ has an N-terminal cytosolic region with a transcriptional activation domain (TAD), a central basic leucine zipper domain (bZIP), and a transmembrane domain followed by a C-terminal luminal region; (B) The cytosolic region is liberated from the ER membrane by S1P and S2P Golgi proteases in a process called regulated intramembrane proteolysis (RIP). The TAD of the N-terminal fragment contains an eight-amino acid sequence, from amino acids 61 to 68 , called the VN8, which confers high transcriptional activity and rapid degradation; (C) Full length ATF6 $\beta$ has a similar structure to ATF6 $\alpha$ and its cytosolic region is also liberated from the ER membrane by S1P and S2P mediated RIP; (D) The N-terminal region of the soluble portion of ATF6 $\beta$ has low homology to ATF6 $\alpha$ and, in particular, lacks the VN8 domain. $\mathrm{N}-\mathrm{ATF} 6 \beta$ is thus a weak transcriptional activator with a long half-life.

\section{ATF6 $\alpha$ Promoter Elements}

The specific promoter sequences to which ATF6 $\alpha$ binds were first reported by Kazutori Mori's group and were named ER stress response elements (ERSEs) [63]. In that study, it was shown that the consensus sequence of ERSEs is CCAAT-N - -CCACG, which includes the binding sites for both NF-Y (CCAAT) and the ATF6 $\alpha$ dimer itself (CCACG) with a nine-nucleotide spacer in between [63]. Subsequent studies identified variations of this sequence, as well as an entirely new ERSE, ERSE-II, the sequence of which, AATTG-N-CCACG, was also found to be important for the ATF6 $\alpha$ transcriptional program [64].

\section{ATF6 $\alpha$ Transcriptional Programs}

In the heart, ATF6 $\alpha$ induces at least 400 gene transcripts in vivo; many of these genes have ERSE or ERSE-like elements [65]. RNAseq performed on mouse hearts expressing a tamoxifen-activatable form of ATF $6 \alpha$ revealed a wide range of upregulated transcripts involved in many critical processes [66]. As one would expect, many of these gene products are directly involved in the adaptive ER stress response and act to enhance ER protein folding capacity under adverse conditions. These gene products include those that encode ER luminal chaperones like GRP78 and GRP94 [63,67] or PDIs like PDIA6 [68] which, in addition to roles in the activation of the ER stress sensors, bind nascent proteins in the ER and 
promote their correct folding into secondary and tertiary structures by facilitating disulfide bond formation [68]. Another subset of ATF6 $\alpha$-regulated genes is involved in ER-associated degradation (ERAD) pathways. Terminally misfolded proteins cannot be repaired and must therefore be targeted for degradation before they build up and become potentially toxic. Because there are no proteasomes in the ER lumen, these proteins must be transported to the cytosol for degradation [69,70]. Intimately involved in this process is the ATF6 $\alpha$-inducible gene product, HMG-CoA reductase degradation protein 1 (Hrd1), an ER transmembrane E3 ubiquitin ligase that both transports misfolded proteins out of the ER and ubiquitylates them, after which they are degraded by proteasomes on the cytosolic face of the ER [71,72]. Interestingly, Hrd1 was the only transmembrane E3 ubiquitin ligase induced by ATF6 $\alpha$ in the heart $[65,73]$. Other ERAD components that are induced by ATF6 include degradation in ER protein 3 (Derlin3) [74] and VCP-interacting membrane protein (VIMP) [75]. These proteins preserve ER proteostasis and enhance cell survival $[76,77]$ and thus, ATF6 $\alpha$ is commonly associated with the adaptive ER stress response [78,79]. However, persistent ER stress and ATF6 $\alpha$ activation can activate maladaptive pathways, which guide the cell towards apoptosis [80,81]. Amongst these maladaptive ATF6 $\alpha$ transcriptional targets is CHOP [82-84], which induces apoptotic signaling, showing that ATF $6 \alpha$ is not always adaptive in a protective sense. Other candidates revealed in RNAseq datasets as ATF6 $\alpha$-regulated genes in the heart, and confirmed in recent discoveries, are non-canonical ATF6 $\alpha$ transcriptional targets that are not directly involved in ER protein homeostasis. For example, the well-known antioxidant enzyme catalase, which is found in peroxisomes and not in the ER, is induced by ATF6 $\alpha$ in the heart [75]. Therefore, by inducing catalase, ATF6 $\alpha$ can reduce the levels of reactive oxygen species (ROS), which has functional implications far beyond ER proteostasis. Another example of a non-canonical ATF6-regulated gene product is the small GTPase Ras homolog enriched in brain (Rheb), which, when induced by ATF6 $\alpha$ in the heart, activates mammalian target of rapamycin complex 1 (mTORC1) and thus drives protein synthesis and hypertrophic cardiac myocyte growth [66]. Again, this indirectly affects ER protein folding but further shows how ATF6 $\alpha$ can be a master regulator of global cellular responses.

\section{Stimulus-Specific ATF6 $\alpha$ Transcriptional Programs}

Recently, it has been found that a wide range of cellular stresses can activate ATF $6 \alpha$; intriguingly, the transcriptional programs regulated by ATF6 $\alpha$ appear to be stress specific [66]. For example, the canonical ATF6 $\alpha$-target gene product, GRP78, which is directly involved in protein folding in the ER, is induced by conditions that acutely increase ER protein misfolding (Figure 4A); however, the more recently identified ATF6 $\alpha$-regulated gene product, catalase, a peroxisomal anti-oxidant enzyme, is induced mainly by ATF6 $\alpha$ when it is activated by oxidative stress, but not when ATF6 $\alpha$ is activated by ER protein misfolding (Figure 4B). Finally, Rheb, which is not induced by ATF6 $\alpha$ when it is activated by oxidative stress, is induced by ATF $6 \alpha$ when it is activated by growth signals; under these conditions, which were studied in the heart, ATF6 $\alpha$ was required for cardiac myocyte growth in response to phenylephrine treatment (Figure 4C). Another recent study by Tam et. al. revealed that ATF6 is selectively activated by the sphingolipids dihydrosphingosine (DHS) and dihydroceramide (DHC) [37]. Like treatment with compound 147, activation is limited to ATF6 $\alpha$ and there is no general induction of ER stress (Figure 2B). Uniquely, however, this mode of activation causes ATF6 $\alpha$ to induce a previously unknown ATF6 $\alpha$-regulated transcriptional program involved in enhancing lipid production for membrane expansion [37]. Given that ATF6 $\alpha$ activation in all these scenarios still appears to involve the canonical ER-Golgi-nucleus pathway, it is unclear how each stimulus directs ATF6 $\alpha$ to a specific subset of genes. It is likely that there are critical roles being played by thus far unknown post-translational modifications, binding partners, and epigenetic regulators which are induced by each stimulus and guide ATF6 $\alpha$ to the appropriate gene set. 


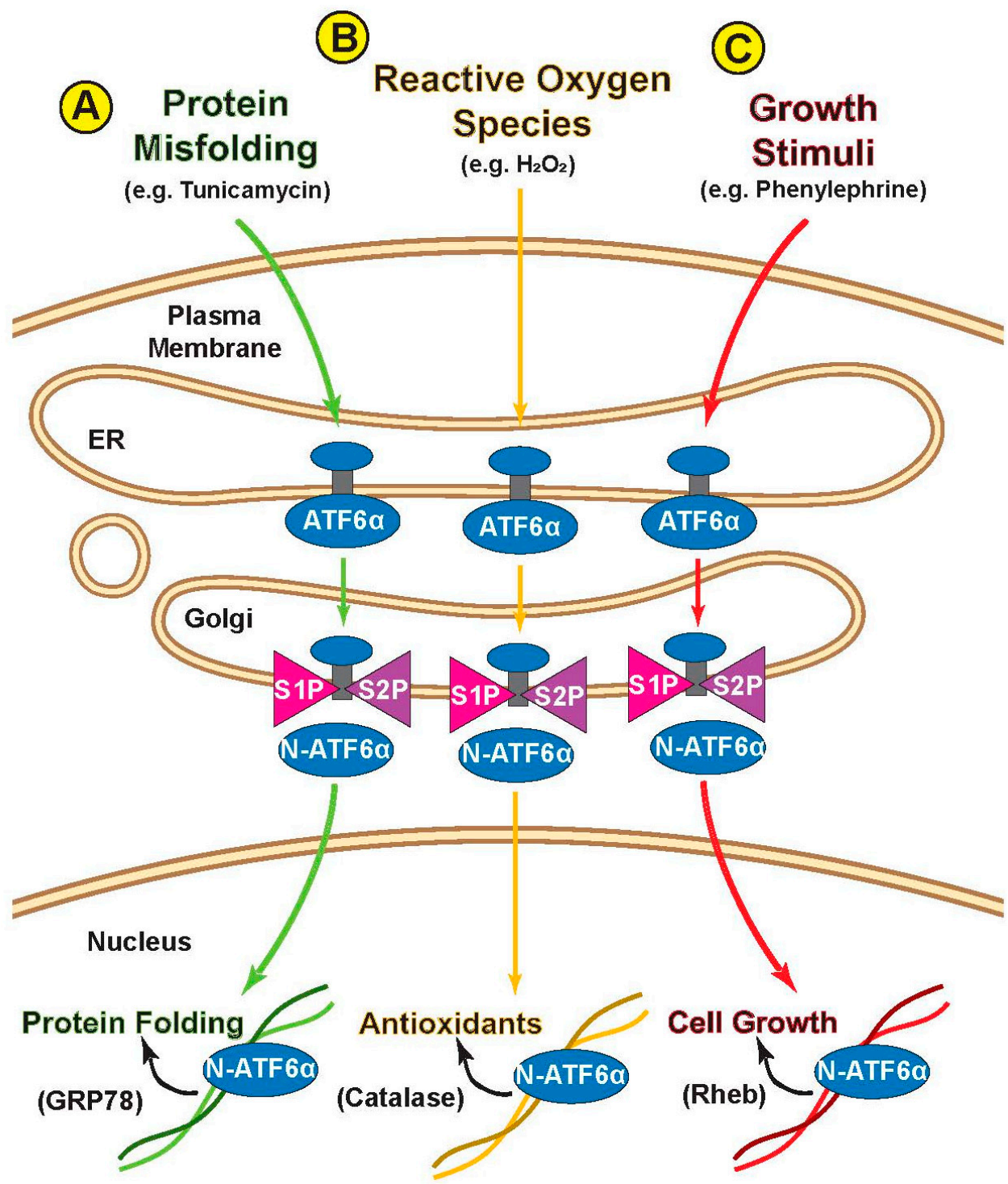

Figure 4. Stimulus-specific transcriptional programs for ATF6 $\alpha$. Different stimuli cause ATF6 $\alpha$ to induce different transcriptional targets, depending on the stimulus, despite activating ATF6 $\alpha$ in apparently similar ways. (A) N-ATF6 $\alpha$ induces canonical ER chaperone GRP78 in response to protein misfolding; (B) N-ATF6 $\alpha$ upregulates antioxidant catalase, but only in response to oxidative stress; (C) $\mathrm{N}-\mathrm{ATF} 6 \alpha$ upregulates cell growth inducer Rheb, but only in response to growth signals.

\section{ATF6 $\alpha$ in Disease}

Transcriptional regulation of a transcriptional program as extensive as that mediated by ATF6 $\alpha$ naturally has profound consequences in a variety of disease states. For example, protein aggregation is a common feature of cardiomyopathy and, in numerous studies of ATF6 $\alpha$ in the heart, it has been consistently found to play protective roles in multiple forms of cardiac injury [23,28,66,75,85-87]. Martindale et. al. overexpressed a tamoxifen activatable form of ATF6 in mouse hearts and then performed ex vivo global ischemia reperfusion on the isolated mouse hearts. Hearts with activated ATF $6 \alpha$ had significantly smaller infarcts and improved cardiac function compared to control [85]. In a later study, Lynch et. al. investigated Thbs4 in hearts from mutant mice that constitutively develop a buildup of cardiac misfolded protein aggregates. They found that Thbs 4 was protective against such aggregates because of its role in the activation of ATF6 $\alpha$ [28]. More recently, Jin et. al. performed ischemia/reperfusion surgeries in mice, where damage to the heart is due mainly to the generation of ROS upon reperfusion. Endogenous ATF6 $\alpha$ was found to be activated by this injury and was shown 
to be protective because it induces the antioxidant, catalase [75]. Blackwood et. al. discovered that ATF $6 \alpha$ was necessary for compensatory cardiac growth in response to pressure overload induced by transaortic constriction (TAC) surgeries, which mimic chronic high blood pressure, due to its induction of the mTORC1 activator Rheb [66]. In a subsequent publication, exploring the use of compound 147 as a drug, Blackwood et al. found 147 to be globally protective against ischemia/reperfusion models in the heart, kidney, and brain [87]. ATF6 $\alpha$ and the ER stress response are generally found to be highly activated in professional secretory cells, due to the increased protein flux through the ER. Sharma and colleagues accordingly found ATF6 $\alpha$ contributes to beta cell proliferation in the pancreas, with implications for diabetes [88]. The ER stress response is also highly active in cancer cells, which, in addition to rapid proliferation, must also survive in the hypoxic environment inside tumors. Indeed, ATF6 $\alpha$ confers chemoresistance in leukemia cells [29]. Lastly, naturally occurring ATF6 $\alpha$ mutations have been found in humans that can alter its activation in response to ER stress. Certain single nucleotide polymorphisms that increase the amount of ATF6 $\alpha$ signaling have been associated with increases in blood cholesterol in patients at risk of cardiovascular disease, potentially because ATF6 $\alpha$ may interact with the SREBP2 lipid biosynthesis pathway [86]. Other mutations that lead to the truncation and degradation of ATF $6 \alpha$ transcript have been shown to cause the autosomal recessive eye disorder achromatopsia, which is characterized by non-functional cone cells, resulting in color-blindness, photophobia, and other maladies [89].

\section{ATF6 $\alpha$ Relatives}

While the importance of the varied and complex outcomes of ATF6 $\alpha$ signaling is apparent in multiple tissues and disease states, it is important to note that ATF6 $\alpha$ is related to other transcription factors, many of which are often included in the large ATF/CREB family [16,17]. Like ATF6 $\alpha$, all members of the ATF/CREB family are bZIP transcription factors consisting of a basic DNA binding region next to an alpha-helical coiled coil region for dimerization. While it is this domain that is the basis of their grouping as a family, the wider structure, distribution, mode of activation, and functions of these family members can vary greatly [52,62]. Amongst these ATF/CREB family members, only a subset are type II ER-transmembrane transcription factors that, like ATF $6 \alpha$, are activated by proteolytic cleavage by Golgi-resident S1P/S2P proteases. In the literature, this subfamily is alternatively named for ATF6 [90], CREB3 (Luman) [91], or, as in this review, for old astrocyte specifically induced substance (OASIS) [92]. The OASIS subfamily includes Luman, primarily expressed in ganglionic neurons, monocytes, and dendritic cells [93]; OASIS, expressed in osteoblasts and astrocytes and involved in bone development [94,95]; box B-binding factor 2 human homolog on chromosome 7 (BBF2H7), expressed in chondrocytes and critical for cartilage development [95,96]; cAMP response element binding $\mathrm{H}(\mathrm{CREBH})$, expressed in the liver and known to heterodimerize with ATF6 $\alpha$ [60]; CREB4, expressed in the prostate and intestines [97]; and ATF6 $\beta$ discussed below. In all cases the liberated cytosolic N-terminal fragment is a bZIP transcription factor with a high degree of structural homology to the activated form of ATF $6 \alpha$, including an N-terminally located TAD and a C-terminal bZIP DNA binding/dimerization domain $[16,90,92]$. However, none have a TAD sequence that is homologous to that of ATF6 $\alpha$ [39] (Figure 5). Additionally, the luminal regions of the rest of the OASIS subfamily (except for ATF6 $\beta$ ) do not resemble ATF6 $\alpha$. In particular, some lack GRP78 binding domains and do not have apparent Golgi localization sequences [92]. Thus, the specific mechanism of activation for some family members is obscure. Many OASIS members have tissue specificity in terms of their expression, while ATF6 $\alpha$ is broadly expressed in all tissues [92,95]. OASIS members also bind to differing promoter sequences. Some are known to bind to ERSE, unfolded protein response elements (UPRE), or otherwise ATF6-like sequences, while others show preference to CRE or CRE-like promoter elements $[90,92]$. It is unclear to what degree OASIS members are involved in ER stress. Some are activated by ER stress and some are not [90-92]. Like the rest of the ATF/CREB family, they form homodimers in order to bind DNA and activate transcription and have the potential to heterodimerize with similar transcription factors, including ATF6 $\alpha[90,92,98]$. 

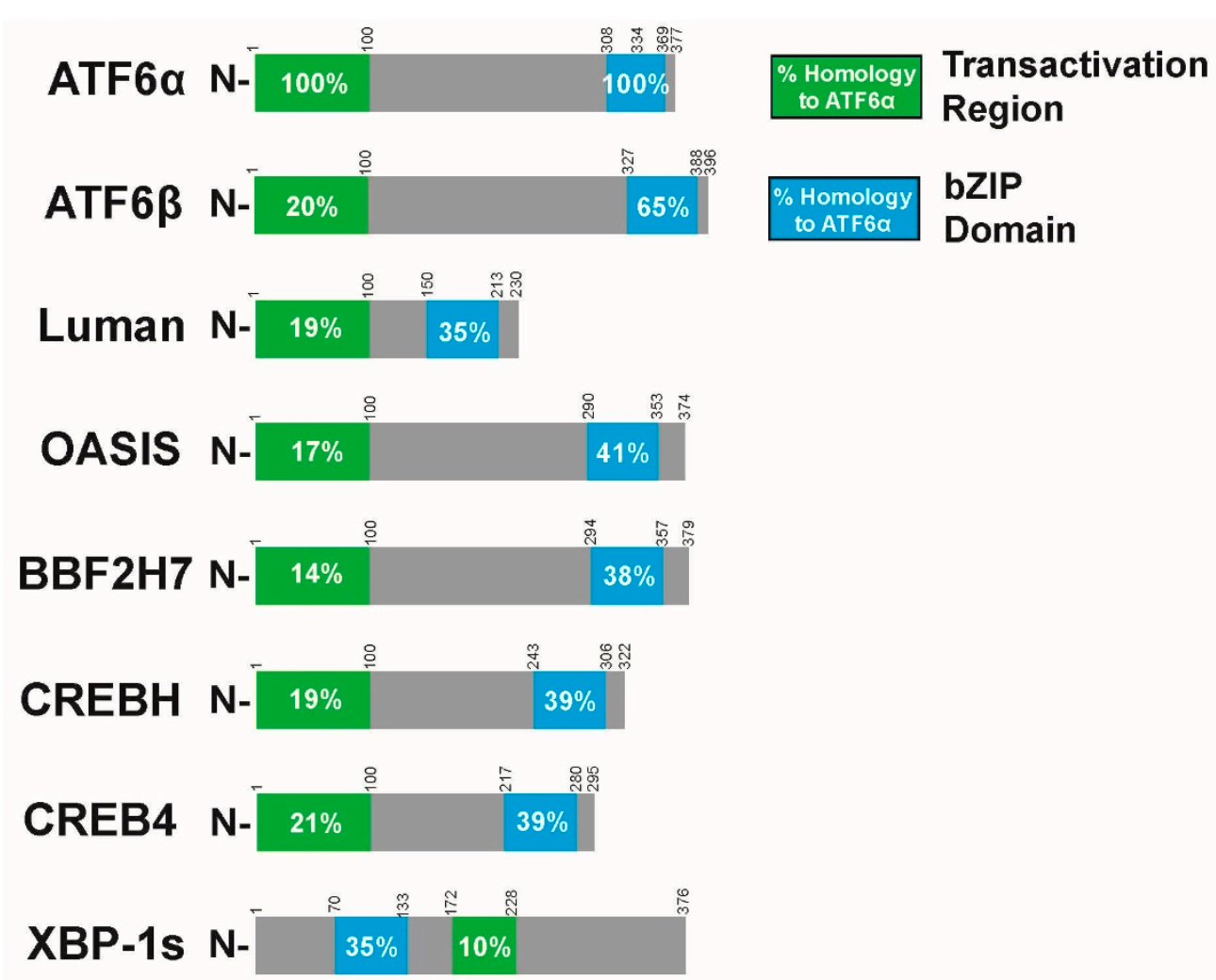

Figure 5. Sequence homologies to soluble N-terminal ATF6 $\alpha$ amongst OASIS family members. While all OASIS members have similar structure in their N-terminal fragments, they have low sequence homology to ATF6 $\alpha$ in their TADs. There is greater homology, however, in their bZIP domains, especially for the member most closely related to ATF6 $\alpha$, ATF6 $\beta$. Fellow ER stress effector XBP-1s, which is a bZIP transcription factor but is not in the OASIS subfamily, is included here for comparison.

\section{ATF6 $\beta$}

In terms of amino acid sequence, ATF6 $\beta$ is the most closely related OASIS subfamily member to ATF6 $\alpha$ and the two together are sometimes considered to form their own subfamily $[16,19]$. Like ATF6 $\alpha$, ATF6 $\beta$ is an ER transmembrane protein with an N-terminal bZIP domain that is liberated by Golgi proteases upon ER stress [20]. ATF6 $\beta$ has significant sequence homology to ATF6 $\alpha$, not only in its bZIP and transmembrane domains, which it shares with the OASIS subfamily members (Figure 5), but also in other areas of its cytosolic and luminal domains [19,20]. Again, however, one area of noted difference is in its TAD, which lacks the critical eight amino acid VN8 sequence found in ATF6 $\alpha$ [18]. When activated, ATF6 $\beta$ is a relatively weak transcriptional activator with a long half-life. Because ATF $6 \beta$ can both bind the same ERSE regions and form heterodimers with ATF6 $\alpha$, it can thus slow the activity of $\alpha$ and function as a transcriptional repressor [18,41,99]. However, it has more recently been shown to upregulate at least some of the same transcripts as ATF $6 \alpha$. Given its greater stability it thus may be able to compensate in model systems in which ATF6 $\alpha$ has been deleted, a hypothesis that agrees with the fact that while either ATF6 $\alpha$ or $\beta$ knockout mice survive to adulthood, double-knockouts are embryonic lethal [100].

\section{Conclusions}

Though ATF6 $\alpha$ is just one transcription factor in the ATF/CREB family, and among more than 2000 transcription factors $[4,101]$ encoded in the mammalian genome, it provides an illuminating case study highlighting the complex regulation that can occur with such a tightly controlled master switch for multiple signaling pathways. Because ATF $6 \alpha$ is so essential to cell survival and function during numerous environmental stresses, and because it is so highly conserved and ubiquitously 
expressed amongst eukaryotes, it becomes clear why it is subject to such finely tuned control networks. Understanding the intricacies of each step in ATF6 $\alpha$ activation can provide insights, and perhaps lead to the identification of potentially druggable regulatory circuits for treating a variety of human diseases. Care must be taken to avoid painting ATF6 $\alpha$ and other similarly important transcriptional regulators with too broad a brush, pigeonholing them into "known" or "canonical" pathways. New and complex regulatory circuits are continually being uncovered and explored, likely revealing undiscovered roles these signal transducers play. As is so often the case, when discussing transcriptional regulation, the devil is in the details.

Author Contributions: Conceptualization, W.T.S., C.C.G., A.A., and E.A.B.; funding acquisition, C.C.G., W.T.S., A.A., and E.A.B.; resources, C.C.G.; supervision, C.C.G.; visualization, W.T.S.; writing-original draft preparation, W.T.S.; writing-review and editing, W.T.S., C.C.G., A.A., and E.A.B. All authors have read and agreed to the published version of the manuscript.

Funding: This research was funded by the American Heart Association (17PRE33670796), the National Institutes of Health (1F31HL140850, R01HL135893, R01 HL141463 and R01 HL149931) (C.C.G.), the San Diego State University (SDSU) Heart Institute (W.T.S., A.A., E.A.B., and C.C.G.), the Inamori Foundation (E.A.B.), and the ARCS Foundation, Inc, San Diego Chapter (W.T.S. and E.A.B). Additionally, W.T.S., A.A., and E.A.B are Rees-Stealy Research Foundation Phillips Gausewitz, M.D., Scholars of the SDSU Heart Institute.

Conflicts of Interest: The authors declare no conflict of interest. The funders had no role in the design of the study; in the collection, analyses, or interpretation of data; in the writing of the manuscript, or in the decision to publish the results.

\section{Abbreviations}

$\begin{array}{ll}\text { ER } & \text { endoplasmic reticulum } \\ \text { ATF6 } \alpha & \text { activating transcription factor } 6 \text { alpha } \\ \text { bZIP } & \text { basic leucine zipper } \\ \text { HIF1 } \alpha & \text { hypoxia inducible factor 1 alpha } \\ \text { NRF2 } & \text { nuclear factor erythroid 2-related factor 2 } \\ \text { SRF } & \text { serum response factor } \\ \text { UPR } & \text { unfolded protein response } \\ \text { PERK } & \text { protein kinase R-like ER kinase } \\ \text { IRE1 } & \text { inositol-requiring protein 1 } \\ \text { eIF2 } \alpha & \text { eukaryotic initiation factor 2 alpha } \\ \text { XBP-1 } & \text { x-box-binding protein 1 } \\ \text { ATF/CREB } & \text { activating transcription factor/cAMP response element binding } \\ \text { GRP78 } & \text { glucose-regulated protein 78 } \\ \text { BiP } & \text { binding immunoglobulin protein } \\ \text { RIP } & \text { regulated intramembrane proteolysis } \\ \text { S1P } & \text { site-1 protease } \\ \text { S2P } & \text { site-2 protease } \\ \text { Thbs4 } & \text { thrombospondin 4 } \\ \text { PDI } & \text { protein disulfide isomerase } \\ \text { PDIA5 } & \text { protein disulfide isomerase A5 } \\ \text { ERp18 } & \text { endoplasmic reticulum protein 18 } \\ \text { AEBSF } & \text { 4-(2-aminoethyl)benzenesulfonyl fluoride } \\ \text { SREBP } & \text { sterol regulatory element binding protein } \\ \text { TAD } & \text { transcriptional activation domain } \\ \text { SUG-1 } & \text { protease regulatory subunit } 8 \text { homolog } \\ \text { SRE } & \text { serum response elements } \\ \text { NF-Y } & \text { nuclear transcription factor Y } \\ \text { YY-1 } & \text { yin-yang 1 } \\ \text { XBP-1s } & \text { X-box binding protein 1 spliced } \\ \text { PGC-1 } \alpha & \text { Peroxisome proliferator-activated receptor gamma coactivator } 1 \text { alpha } \\ & \end{array}$




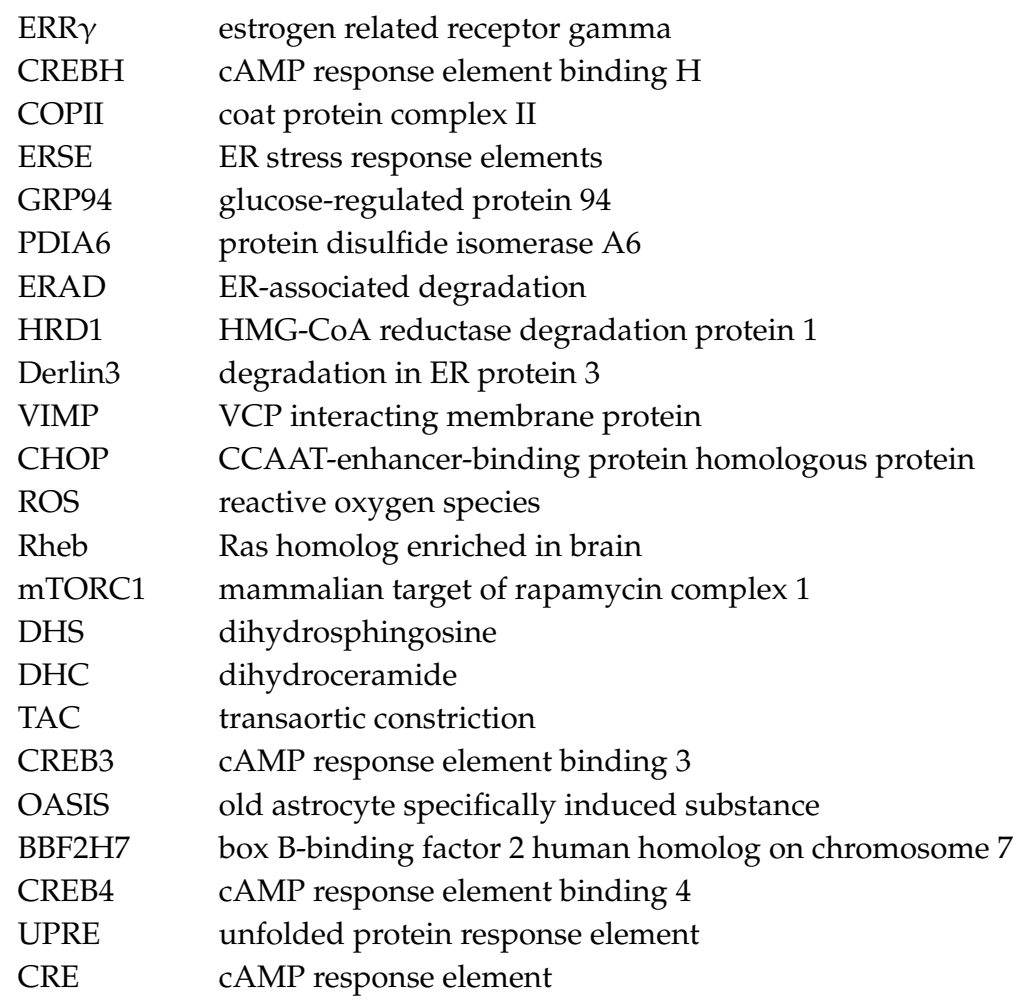

\section{References}

1. Klemm, S.L.; Shipony, Z.; Greenleaf, W.J. Chromatin accessibility and the regulatory epigenome. Nat. Rev. Genet. 2019, 20, 207-220. [CrossRef]

2. Spitz, F.; Furlong, E.E. Transcription factors: From enhancer binding to developmental control. Nat. Rev. Genet. 2012, 13, 613-626. [CrossRef]

3. Lodish, H.F.; Berk, A.; Kaiser, C.A.; Krieger, M.; Bretscher, A.; Ploegh, H.; Amon, A.; Martin, K.C. Molecular Cell Biology, 8th ed.; Macmillan: New York, NY, USA, 2008; pp. xl, 1170, G-1128, I-1136.

4. Lambert, S.A.; Jolma, A.; Campitelli, L.F.; Das, P.K.; Yin, Y.; Albu, M.; Chen, X.; Taipale, J.; Hughes, T.R.; Weirauch, M.T. The Human Transcription Factors. Cell 2018, 175, 598-599. [CrossRef]

5. Johnson, P.F.; McKnight, S.L. Eukaryotic transcriptional regulatory proteins. Annu. Rev. Biochem. 1989, 58, 799-839. [CrossRef]

6. Hill, C.S.; Treisman, R. Transcriptional regulation by extracellular signals: Mechanisms and specificity. Cell 1995, 80, 199-211. [CrossRef]

7. Prabhakar, N.R.; Semenza, G.L. Oxygen Sensing and Homeostasis. Physiology 2015, 30, 340-348. [CrossRef] [PubMed]

8. Shaw, P.; Chattopadhyay, A. Nrf2-ARE signaling in cellular protection: Mechanism of action and the regulatory mechanisms. J. Cell. Physiol. 2019. [CrossRef] [PubMed]

9. Treisman, R.; Ammerer, G. The SRF and MCM1 transcription factors. Curr. Opin. Genet. Dev. 1992, 2, $221-226$. [CrossRef]

10. Kaufman, R.J. Orchestrating the unfolded protein response in health and disease. J. Clin. Investig. 2002, 110, 1389-1398. [CrossRef]

11. Glembotski, C.C.; Rosarda, J.D.; Wiseman, R.L. Proteostasis and Beyond: ATF6 in Ischemic Disease. Trends Mol. Med. 2019, 25, 538-550. [CrossRef]

12. Walter, P.; Ron, D. The unfolded protein response: From stress pathway to homeostatic regulation. Science 2011, 334, 1081-1086. [CrossRef] [PubMed]

13. Harding, H.P.; Zhang, Y.; Ron, D. Protein translation and folding are coupled by an endoplasmic-reticulum-resident kinase. Nature 1999, 397, 271-274. [CrossRef] [PubMed] 
14. Lee, K.; Tirasophon, W.; Shen, X.; Michalak, M.; Prywes, R.; Okada, T.; Yoshida, H.; Mori, K.; Kaufman, R.J. IRE1-mediated unconventional mRNA splicing and S2P-mediated ATF6 cleavage merge to regulate XBP1 in signaling the unfolded protein response. Genes Dev. 2002, 16, 452-466. [CrossRef] [PubMed]

15. Shen, J.; Prywes, R. ER stress signaling by regulated proteolysis of ATF6. Methods 2005, 35, 382-389. [CrossRef] [PubMed]

16. Hai, T.; Hartman, M.G. The molecular biology and nomenclature of the activating transcription factor/cAMP responsive element binding family of transcription factors: Activating transcription factor proteins and homeostasis. Gene 2001, 273, 1-11. [CrossRef]

17. Amoutzias, G.D.; Veron, A.S.; Weiner, J., 3rd; Robinson-Rechavi, M.; Bornberg-Bauer, E.; Oliver, S.G.; Robertson, D.L. One billion years of bZIP transcription factor evolution: Conservation and change in dimerization and DNA-binding site specificity. Mol. Biol. Evol. 2007, 24, 827-835. [CrossRef]

18. Thuerauf, D.J.; Marcinko, M.; Belmont, P.J.; Glembotski, C.C. Effects of the isoform-specific characteristics of ATF6 alpha and ATF6 beta on endoplasmic reticulum stress response gene expression and cell viability. $J$. Biol. Chem. 2007, 282, 22865-22878. [CrossRef]

19. Haze, K.; Okada, T.; Yoshida, H.; Yanagi, H.; Yura, T.; Negishi, M.; Mori, K. Identification of the G13 (cAMP-response-element-binding protein-related protein) gene product related to activating transcription factor 6 as a transcriptional activator of the mammalian unfolded protein response. Biochem. J. 2001, 355, 19-28. [CrossRef]

20. Shen, J.; Chen, X.; Hendershot, L.; Prywes, R. ER stress regulation of ATF6 localization by dissociation of BiP/GRP78 binding and unmasking of Golgi localization signals. Dev. Cell 2002, 3, 99-111. [CrossRef]

21. Nadanaka, S.; Yoshida, H.; Mori, K. Reduction of disulfide bridges in the lumenal domain of ATF6 in response to glucose starvation. Cell Struct. Funct. 2006, 31, 127-134. [CrossRef]

22. Nadanaka, S.; Okada, T.; Yoshida, H.; Mori, K. Role of disulfide bridges formed in the luminal domain of ATF6 in sensing endoplasmic reticulum stress. Mol. Cell. Biol. 2007, 27, 1027-1043. [CrossRef] [PubMed]

23. Doroudgar, S.; Thuerauf, D.J.; Marcinko, M.C.; Belmont, P.J.; Glembotski, C.C. Ischemia activates the ATF6 branch of the endoplasmic reticulum stress response. J. Biol. Chem. 2009, 284, 29735-29745. [CrossRef] [PubMed]

24. Shen, J.; Snapp, E.L.; Lippincott-Schwartz, J.; Prywes, R. Stable binding of ATF6 to BiP in the endoplasmic reticulum stress response. Mol. Cell. Biol. 2005, 25, 921-932. [CrossRef] [PubMed]

25. Ye, J.; Rawson, R.B.; Komuro, R.; Chen, X.; Dave, U.P.; Prywes, R.; Brown, M.S.; Goldstein, J.L. ER stress induces cleavage of membrane-bound ATF6 by the same proteases that process SREBPs. Mol. Cell 2000, 6, 1355-1364. [CrossRef]

26. Bertolotti, A.; Zhang, Y.; Hendershot, L.M.; Harding, H.P.; Ron, D. Dynamic interaction of BiP and ER stress transducers in the unfolded-protein response. Nat. Cell Biol. 2000, 2, 326-332. [CrossRef]

27. Ma, K.; Vattem, K.M.; Wek, R.C. Dimerization and release of molecular chaperone inhibition facilitate activation of eukaryotic initiation factor-2 kinase in response to endoplasmic reticulum stress. J. Biol. Chem. 2002, 277, 18728-18735. [CrossRef]

28. Lynch, J.M.; Maillet, M.; Vanhoutte, D.; Schloemer, A.; Sargent, M.A.; Blair, N.S.; Lynch, K.A.; Okada, T.; Aronow, B.J.; Osinska, H.; et al. A thrombospondin-dependent pathway for a protective ER stress response. Cell 2012, 149, 1257-1268. [CrossRef]

29. Higa, A.; Taouji, S.; Lhomond, S.; Jensen, D.; Fernandez-Zapico, M.E.; Simpson, J.C.; Pasquet, J.M.; Schekman, R.; Chevet, E. Endoplasmic reticulum stress-activated transcription factor ATF6alpha requires the disulfide isomerase PDIA5 to modulate chemoresistance. Mol. Cell. Biol. 2014, 34, 1839-1849. [CrossRef]

30. Oka, O.B.; van Lith, M.; Rudolf, J.; Tungkum, W.; Pringle, M.A.; Bulleid, N.J. ERp18 regulates activation of ATF6alpha during unfolded protein response. EMBO J. 2019, 38, e100990. [CrossRef]

31. Gallagher, C.M.; Garri, C.; Cain, E.L.; Ang, K.K.; Wilson, C.G.; Chen, S.; Hearn, B.R.; Jaishankar, P.; Aranda-Diaz, A.; Arkin, M.R.; et al. Ceapins are a new class of unfolded protein response inhibitors, selectively targeting the ATF6alpha branch. Elife 2016, 5. [CrossRef]

32. Gallagher, C.M.; Walter, P. Ceapins inhibit ATF6alpha signaling by selectively preventing transport of ATF6alpha to the Golgi apparatus during ER stress. Elife 2016, 5. [CrossRef] [PubMed]

33. Okada, T.; Haze, K.; Nadanaka, S.; Yoshida, H.; Seidah, N.G.; Hirano, Y.; Sato, R.; Negishi, M.; Mori, K. A serine protease inhibitor prevents endoplasmic reticulum stress-induced cleavage but not transport of the membrane-bound transcription factor ATF6. J. Biol. Chem. 2003, 278, 31024-31032. [CrossRef] [PubMed] 
34. Pasquato, A.; Rochat, C.; Burri, D.J.; Pasqual, G.; de la Torre, J.C.; Kunz, S. Evaluation of the anti-arenaviral activity of the subtilisin kexin isozyme-1/site-1 protease inhibitor PF-429242. Virology 2012, 423, 14-22. [CrossRef] [PubMed]

35. Plate, L.; Cooley, C.B.; Chen, J.J.; Paxman, R.J.; Gallagher, C.M.; Madoux, F.; Genereux, J.C.; Dobbs, W.; Garza, D.; Spicer, T.P.; et al. Small molecule proteostasis regulators that reprogram the ER to reduce extracellular protein aggregation. Elife 2016, 5. [CrossRef]

36. Paxman, R.; Plate, L.; Blackwood, E.A.; Glembotski, C.; Powers, E.T.; Wiseman, R.L.; Kelly, J.W. Pharmacologic ATF6 activating compounds are metabolically activated to selectively modify endoplasmic reticulum proteins. Elife 2018, 7. [CrossRef]

37. Tam, A.B.; Roberts, L.S.; Chandra, V.; Rivera, I.G.; Nomura, D.K.; Forbes, D.J.; Niwa, M. The UPR Activator ATF6 Responds to Proteotoxic and Lipotoxic Stress by Distinct Mechanisms. Dev. Cell 2018, 46, 327-343.e327. [CrossRef]

38. Hai, T.W.; Liu, F.; Coukos, W.J.; Green, M.R. Transcription factor ATF cDNA clones: An extensive family of leucine zipper proteins able to selectively form DNA-binding heterodimers. Genes Dev. 1989, 3, 2083-2090. [CrossRef]

39. Thuerauf, D.J.; Morrison, L.E.; Hoover, H.; Glembotski, C.C. Coordination of ATF6-mediated transcription and ATF6 degradation by a domain that is shared with the viral transcription factor, VP16. J. Biol. Chem. 2002, 277, 20734-20739. [CrossRef]

40. Desterro, J.M.; Rodriguez, M.S.; Hay, R.T. Regulation of transcription factors by protein degradation. Cell Mol. Life Sci. 2000, 57, 1207-1219. [CrossRef]

41. Thuerauf, D.J.; Morrison, L.; Glembotski, C.C. Opposing roles for ATF6alpha and ATF6beta in endoplasmic reticulum stress response gene induction. J. Biol. Chem. 2004, 279, 21078-21084. [CrossRef]

42. Fonseca, S.G.; Ishigaki, S.; Oslowski, C.M.; Lu, S.; Lipson, K.L.; Ghosh, R.; Hayashi, E.; Ishihara, H.; Oka, Y.; Permutt, M.A.; et al. Wolfram syndrome 1 gene negatively regulates ER stress signaling in rodent and human cells. J. Clin. Investig. 2010, 120, 744-755. [CrossRef] [PubMed]

43. Kim, W.; Bennett, E.J.; Huttlin, E.L.; Guo, A.; Li, J.; Possemato, A.; Sowa, M.E.; Rad, R.; Rush, J.; Comb, M.J.; et al. Systematic and quantitative assessment of the ubiquitin-modified proteome. Mol. Cell 2011, 44, 325-340. [CrossRef] [PubMed]

44. Hong, M.; Li, M.; Mao, C.; Lee, A.S. Endoplasmic reticulum stress triggers an acute proteasome-dependent degradation of ATF6. J. Cell. Biochem. 2004, 92, 723-732. [CrossRef]

45. Zhu, Q.; Yao, J.; Wani, G.; Chen, J.; Wang, Q.E.; Wani, A.A. The ubiquitin-proteasome pathway is required for the function of the viral VP16 transcriptional activation domain. FEBS Lett. 2004, 556, 19-25. [CrossRef]

46. Hong, M.; Luo, S.; Baumeister, P.; Huang, J.M.; Gogia, R.K.; Li, M.; Lee, A.S. Underglycosylation of ATF6 as a novel sensing mechanism for activation of the unfolded protein response. J. Biol. Chem. 2004, 279, 11354-11363. [CrossRef] [PubMed]

47. Hou, X.; Yang, Z.; Zhang, K.; Fang, D.; Sun, F. SUMOylation represses the transcriptional activity of the Unfolded Protein Response transducer ATF6. Biochem. Biophys Res. Commun. 2017, 494, 446-451. [CrossRef] [PubMed]

48. Geng, F.; Wenzel, S.; Tansey, W.P. Ubiquitin and proteasomes in transcription. Annu. Rev. Biochem. 2012, 81, 177-201. [CrossRef]

49. Freedman, D.A.; Levine, A.J. Nuclear export is required for degradation of endogenous p53 by MDM2 and human papillomavirus E6. Mol. Cell. Biol. 1998, 18, 7288-7293. [CrossRef]

50. Chen, L.; Madura, K. Yeast importin-alpha (Srp1) performs distinct roles in the import of nuclear proteins and in targeting proteasomes to the nucleus. J. Biol. Chem. 2014, 289, 32339-32352. [CrossRef]

51. Dang, F.W.; Chen, L.; Madura, K. Catalytically Active Proteasomes Function Predominantly in the Cytosol. J. Biol. Chem. 2016, 291, 18765-18777. [CrossRef]

52. Rodriguez-Martinez, J.A.; Reinke, A.W.; Bhimsaria, D.; Keating, A.E.; Ansari, A.Z. Combinatorial bZIP dimers display complex DNA-binding specificity landscapes. Elife 2017, 6. [CrossRef] [PubMed]

53. Huet, A.; Parlakian, A.; Arnaud, M.C.; Glandieres, J.M.; Valat, P.; Fermandjian, S.; Paulin, D.; Alpert, B.; Zentz, C. Mechanism of binding of serum response factor to serum response element. FEBS J. 2005, 272, 3105-3119. [CrossRef] [PubMed]

54. Zhu, C.; Johansen, F.E.; Prywes, R. Interaction of ATF6 and serum response factor. Mol. Cell. Biol. 1997, 17, 4957-4966. [CrossRef] [PubMed] 
55. Yoshida, H.; Okada, T.; Haze, K.; Yanagi, H.; Yura, T.; Negishi, M.; Mori, K. ATF6 activated by proteolysis binds in the presence of NF-Y (CBF) directly to the cis-acting element responsible for the mammalian unfolded protein response. Mol. Cell. Biol. 2000, 20, 6755-6767. [CrossRef] [PubMed]

56. Li, M.; Baumeister, P.; Roy, B.; Phan, T.; Foti, D.; Luo, S.; Lee, A.S. ATF6 as a transcription activator of the endoplasmic reticulum stress element: Thapsigargin stress-induced changes and synergistic interactions with NF-Y and YY1. Mol. Cell. Biol. 2000, 20, 5096-5106. [CrossRef] [PubMed]

57. Yamamoto, K.; Sato, T.; Matsui, T.; Sato, M.; Okada, T.; Yoshida, H.; Harada, A.; Mori, K. Transcriptional induction of mammalian ER quality control proteins is mediated by single or combined action of ATF6alpha and XBP1. Dev. Cell 2007, 13, 365-376. [CrossRef]

58. Wu, J.; Ruas, J.L.; Estall, J.L.; Rasbach, K.A.; Choi, J.H.; Ye, L.; Bostrom, P.; Tyra, H.M.; Crawford, R.W.; Campbell, K.P.; et al. The unfolded protein response mediates adaptation to exercise in skeletal muscle through a PGC-1alpha/ATF6alpha complex. Cell Metab. 2011, 13, 160-169. [CrossRef]

59. Misra, J.; Kim, D.K.; Choi, W.; Koo, S.H.; Lee, C.H.; Back, S.H.; Kaufman, R.J.; Choi, H.S. Transcriptional cross talk between orphan nuclear receptor ERRgamma and transmembrane transcription factor ATF6alpha coordinates endoplasmic reticulum stress response. Nucleic Acids Res. 2013, 41, 6960-6974. [CrossRef]

60. Zhang, K.; Shen, X.; Wu, J.; Sakaki, K.; Saunders, T.; Rutkowski, D.T.; Back, S.H.; Kaufman, R.J. Endoplasmic reticulum stress activates cleavage of CREBH to induce a systemic inflammatory response. Cell 2006, 124, 587-599. [CrossRef]

61. Chen, X.; Shen, J.; Prywes, R. The luminal domain of ATF6 senses endoplasmic reticulum (ER) stress and causes translocation of ATF6 from the ER to the Golgi. J. Biol. Chem. 2002, 277, 13045-13052. [CrossRef]

62. Vinson, C.; Acharya, A.; Taparowsky, E.J. Deciphering B-ZIP transcription factor interactions in vitro and in vivo. Biochim. Biophys. Acta. 2006, 1759, 4-12. [CrossRef]

63. Yoshida, H.; Haze, K.; Yanagi, H.; Yura, T.; Mori, K. Identification of the cis-acting endoplasmic reticulum stress response element responsible for transcriptional induction of mammalian glucose-regulated proteins. Involvement of basic leucine zipper transcription factors. J. Biol. Chem. 1998, 273, 33741-33749. [CrossRef] [PubMed]

64. Kokame, K.; Kato, H.; Miyata, T. Identification of ERSE-II, a new cis-acting element responsible for the ATF6-dependent mammalian unfolded protein response. J. Biol. Chem. 2001, 276, 9199-9205. [CrossRef] [PubMed]

65. Belmont, P.J.; Tadimalla, A.; Chen, W.J.; Martindale, J.J.; Thuerauf, D.J.; Marcinko, M.; Gude, N.; Sussman, M.A.; Glembotski, C.C. Coordination of growth and endoplasmic reticulum stress signaling by regulator of calcineurin 1 (RCAN1), a novel ATF6-inducible gene. J. Biol. Chem. 2008, 283, 14012-14021. [CrossRef] [PubMed]

66. Blackwood, E.A.; Hofmann, C.; Santo Domingo, M.; Bilal, A.S.; Sarakki, A.; Stauffer, W.; Arrieta, A.; Thuerauf, D.J.; Kolkhorst, F.W.; Muller, O.J.; et al. ATF6 Regulates Cardiac Hypertrophy by Transcriptional Induction of the mTORC1 Activator, Rheb. Circ. Res. 2019, 124, 79-93. [CrossRef]

67. Haze, K.; Yoshida, H.; Yanagi, H.; Yura, T.; Mori, K. Mammalian transcription factor ATF6 is synthesized as a transmembrane protein and activated by proteolysis in response to endoplasmic reticulum stress. Mol. Biol. Cell 1999, 10, 3787-3799. [CrossRef]

68. Vekich, J.A.; Belmont, P.J.; Thuerauf, D.J.; Glembotski, C.C. Protein disulfide isomerase-associated 6 is an ATF6-inducible ER stress response protein that protects cardiac myocytes from ischemia/reperfusion-mediated cell death. J. Mol. Cell. Cardiol. 2012, 53, 259-267. [CrossRef]

69. Werner, E.D.; Brodsky, J.L.; McCracken, A.A. Proteasome-dependent endoplasmic reticulum-associated protein degradation: An unconventional route to a familiar fate. Proc. Natl. Acad. Sci. USA 1996, 93, 13797-13801. [CrossRef]

70. Hampton, R.Y.; Gardner, R.G.; Rine, J. Role of 26S proteasome and HRD genes in the degradation of 3-hydroxy-3-methylglutaryl-CoA reductase, an integral endoplasmic reticulum membrane protein. Mol. Biol. Cell 1996, 7, 2029-2044. [CrossRef]

71. Nadav, E.; Shmueli, A.; Barr, H.; Gonen, H.; Ciechanover, A.; Reiss, Y. A novel mammalian endoplasmic reticulum ubiquitin ligase homologous to the yeast Hrd1. Biochem. Biophys. Res. Commun. 2003, 303, 91-97. [CrossRef] 
72. Kikkert, M.; Doolman, R.; Dai, M.; Avner, R.; Hassink, G.; van Voorden, S.; Thanedar, S.; Roitelman, J.; Chau, V.; Wiertz, E. Human HRD1 is an E3 ubiquitin ligase involved in degradation of proteins from the endoplasmic reticulum. J. Biol. Chem. 2004, 279, 3525-3534. [CrossRef] [PubMed]

73. Doroudgar, S.; Volkers, M.; Thuerauf, D.J.; Khan, M.; Mohsin, S.; Respress, J.L.; Wang, W.; Gude, N.; Muller, O.J.; Wehrens, X.H.; et al. Hrd1 and ER-Associated Protein Degradation, ERAD, are Critical Elements of the Adaptive ER Stress Response in Cardiac Myocytes. Circ. Res. 2015, 117, 536-546. [CrossRef] [PubMed]

74. Belmont, P.J.; Chen, W.J.; San Pedro, M.N.; Thuerauf, D.J.; Gellings Lowe, N.; Gude, N.; Hilton, B.; Wolkowicz, R.; Sussman, M.A.; Glembotski, C.C. Roles for endoplasmic reticulum-associated degradation and the novel endoplasmic reticulum stress response gene Derlin-3 in the ischemic heart. Circ. Res. 2010, 106, 307-316. [CrossRef] [PubMed]

75. Jin, J.K.; Blackwood, E.A.; Azizi, K.; Thuerauf, D.J.; Fahem, A.G.; Hofmann, C.; Kaufman, R.J.; Doroudgar, S.; Glembotski, C.C. ATF6 Decreases Myocardial Ischemia/Reperfusion Damage and Links ER Stress and Oxidative Stress Signaling Pathways in the Heart. Circ. Res. 2017, 120, 862-875. [CrossRef] [PubMed]

76. Oda, Y.; Okada, T.; Yoshida, H.; Kaufman, R.J.; Nagata, K.; Mori, K. Derlin-2 and Derlin-3 are regulated by the mammalian unfolded protein response and are required for ER-associated degradation. J. Cell. Biol. 2006, 172, 383-393. [CrossRef]

77. Reeves, M.A.; Hoffmann, P.R. The human selenoproteome: Recent insights into functions and regulation. Cell. Mol. Life Sci. 2009, 66, 2457-2478. [CrossRef]

78. Glembotski, C.C. Roles for ATF6 and the sarco/endoplasmic reticulum protein quality control system in the heart. J. Mol. Cell. Cardiol. 2014, 71, 11-15. [CrossRef]

79. Wu, J.; Rutkowski, D.T.; Dubois, M.; Swathirajan, J.; Saunders, T.; Wang, J.; Song, B.; Yau, G.D.; Kaufman, R.J. ATF6alpha optimizes long-term endoplasmic reticulum function to protect cells from chronic stress. Dev. Cell 2007, 13, 351-364. [CrossRef]

80. Kaufman, R.J. Stress signaling from the lumen of the endoplasmic reticulum: Coordination of gene transcriptional and translational controls. Genes Dev. 1999, 13, 1211-1233. [CrossRef]

81. Marciniak, S.J.; Yun, C.Y.; Oyadomari, S.; Novoa, I.; Zhang, Y.; Jungreis, R.; Nagata, K.; Harding, H.P.; Ron, D. $\mathrm{CHOP}$ induces death by promoting protein synthesis and oxidation in the stressed endoplasmic reticulum. Genes Dev. 2004, 18, 3066-3077. [CrossRef]

82. Ubeda, M.; Habener, J.F. CHOP gene expression in response to endoplasmic-reticular stress requires NFY interaction with different domains of a conserved DNA-binding element. Nucleic Acids Res. 2000, 28, 4987-4997. [CrossRef] [PubMed]

83. Gotoh, T.; Oyadomari, S.; Mori, K.; Mori, M. Nitric oxide-induced apoptosis in RAW 264.7 macrophages is mediated by endoplasmic reticulum stress pathway involving ATF6 and CHOP. J. Biol. Chem. 2002, 277, 12343-12350. [CrossRef] [PubMed]

84. Oyadomari, S.; Mori, M. Roles of CHOP/GADD153 in endoplasmic reticulum stress. Cell Death. Differ. 2004, 11, 381-389. [CrossRef]

85. Martindale, J.J.; Fernandez, R.; Thuerauf, D.; Whittaker, R.; Gude, N.; Sussman, M.A.; Glembotski, C.C. Endoplasmic reticulum stress gene induction and protection from ischemia/reperfusion injury in the hearts of transgenic mice with a tamoxifen-regulated form of ATF6. Circ. Res. 2006, 98, 1186-1193. [CrossRef]

86. Meex, S.J.; Weissglas-Volkov, D.; van der Kallen, C.J.; Thuerauf, D.J.; van Greevenbroek, M.M.; Schalkwijk, C.G.; Stehouwer, C.D.; Feskens, E.J.; Heldens, L.; Ayoubi, T.A.; et al. The ATF6-Met[67]Val substitution is associated with increased plasma cholesterol levels. Arterioscler. Thromb. Vasc. Biol. 2009, 29, 1322-1327. [CrossRef]

87. Blackwood, E.A.; Azizi, K.; Thuerauf, D.J.; Paxman, R.J.; Plate, L.; Kelly, J.W.; Wiseman, R.L.; Glembotski, C.C. Pharmacologic ATF6 activation confers global protection in widespread disease models by reprograming cellular proteostasis. Nat. Commun. 2019, 10, 187. [CrossRef]

88. Sharma, R.B.; O’Donnell, A.C.; Stamateris, R.E.; Ha, B.; McCloskey, K.M.; Reynolds, P.R.; Arvan, P.; Alonso, L.C. Insulin demand regulates beta cell number via the unfolded protein response. J. Clin. Investig. 2015, 125, 3831-3846. [CrossRef]

89. Kohl, S.; Zobor, D.; Chiang, W.C.; Weisschuh, N.; Staller, J.; Gonzalez Menendez, I.; Chang, S.; Beck, S.C.; Garcia Garrido, M.; Sothilingam, V.; et al. Mutations in the unfolded protein response regulator ATF6 cause the cone dysfunction disorder achromatopsia. Nat. Genet. 2015, 47, 757-765. [CrossRef] 
90. Bailey, D.; O'Hare, P. Transmembrane bZIP transcription factors in ER stress signaling and the unfolded protein response. Antioxid. Redox Signal. 2007, 9, 2305-2321. [CrossRef]

91. Chan, C.P.; Kok, K.H.; Jin, D.Y. CREB3 subfamily transcription factors are not created equal: Recent insights from global analyses and animal models. Cell Biosci. 2011, 1, 6. [CrossRef]

92. Asada, R.; Kanemoto, S.; Kondo, S.; Saito, A.; Imaizumi, K. The signalling from endoplasmic reticulum-resident bZIP transcription factors involved in diverse cellular physiology. J. Biochem. 2011, 149, 507-518. [CrossRef] [PubMed]

93. DenBoer, L.M.; Hardy-Smith, P.W.; Hogan, M.R.; Cockram, G.P.; Audas, T.E.; Lu, R. Luman is capable of binding and activating transcription from the unfolded protein response element. Biochem. Biophys. Res. Commun 2005, 331, 113-119. [CrossRef] [PubMed]

94. Omori, Y.; Imai, J.; Suzuki, Y.; Watanabe, S.; Tanigami, A.; Sugano, S. OASIS is a transcriptional activator of CREB/ATF family with a transmembrane domain. Biochem. Biophys. Res. Commun 2002, 293, 470-477. [CrossRef]

95. Horiuchi, K.; Tohmonda, T.; Morioka, H. The unfolded protein response in skeletal development and homeostasis. Cell. Mol. Life Sci. 2016, 73, 2851-2869. [CrossRef]

96. Kondo, S.; Saito, A.; Hino, S.; Murakami, T.; Ogata, M.; Kanemoto, S.; Nara, S.; Yamashita, A.; Yoshinaga, K.; Hara, H.; et al. BBF2H7, a novel transmembrane bZIP transcription factor, is a new type of endoplasmic reticulum stress transducer. Mol. Cell. Biol. 2007, 27, 1716-1729. [CrossRef]

97. Stirling, J.; O'Hare, P. CREB4, a transmembrane bZip transcription factor and potential new substrate for regulation and cleavage by S1P. Mol. Biol. Cell 2006, 17, 413-426. [CrossRef]

98. Kondo, S.; Saito, A.; Asada, R.; Kanemoto, S.; Imaizumi, K. Physiological unfolded protein response regulated by OASIS family members, transmembrane bZIP transcription factors. Iubmb Life 2011, 63, $233-239$. [CrossRef]

99. Forouhan, M.; Mori, K.; Boot-Handford, R.P. Paradoxical roles of ATF6alpha and ATF6beta in modulating disease severity caused by mutations in collagen X. Matrix Biol. 2018, 70, 50-71. [CrossRef]

100. Correll, R.N.; Grimes, K.M.; Prasad, V.; Lynch, J.M.; Khalil, H.; Molkentin, J.D. Overlapping and differential functions of ATF6alpha versus ATF6beta in the mouse heart. Sci. Rep. 2019, 9, 2059. [CrossRef]

101. Vaquerizas, J.M.; Kummerfeld, S.K.; Teichmann, S.A.; Luscombe, N.M. A census of human transcription factors: Function, expression and evolution. Nat. Rev. Genet. 2009, 10, 252-263. [CrossRef]

(C) 2020 by the authors. Licensee MDPI, Basel, Switzerland. This article is an open access article distributed under the terms and conditions of the Creative Commons Attribution (CC BY) license (http://creativecommons.org/licenses/by/4.0/). 